\title{
Formal Participation in the IASB's Due Process of Standard Setting: A Multi-Issue/Multi-Period Analysis
}

\author{
Ann Jorissen \\ University of Antwerp - Department of Accounting \& Finance \\ Nadine Lybaert \\ Hasselt University \\ $\underline{\text { Raf Orens }}$ \\ Catholic University of Louvain (UCL) - Lessius University College
}

Leo Van der Tas

Tilburg University; Ernst \& Young, The Netherlands

European Accounting Review, Forthcoming

\begin{abstract}
:
This paper sets out to enquire the nature of constituents' participation in the IASB's due process in terms of representation (constituents' diversity and characteristics) and drivers to participate. We choose to adopt a multi-issue/multi-period approach to investigate constituents' formal participation. An analysis of comment letters sent directly to the IASB over the period 2002-2006, reveals that preparers sent most letters followed by the accounting profession and standard setters. With regard to timing, we find that preparers concentrate their participation efforts at a later stage in the process compared to the other constituents, who react earlier. Formal indirect participation in the IASB's due process by submitting comments letters to EFRAG is infrequently used by European constituents. In those cases where constituents exert influence to both IASB and EFRAG, they often use exactly the same comment letter. Concentrating on the drivers to participate, the data reveal that preparers, accountants and standard setters react significantly more when proposals have a major impact on the accounting numbers of a company. Users, stock exchanges and their supervisory authorities write significantly more comment letters when disclosure issues are at stake. Finally, participating preparers in the IASB's due process are larger and more profitable than non-participating preparers.
\end{abstract}

Keywords: IASB, standard setting, IAS/IFRS, lobbying, constituents' diversity, multi-issue/multi-period approach 